\title{
The Role of Sensing Capability in Enhancing Small Business Performance
}

\author{
Lasmy $^{1 *}$, Tirta Nugraha Mursitama ${ }^{2}$, Asnan Furinto ${ }^{3}$ and Setyo Hari Wijanto ${ }^{4}$

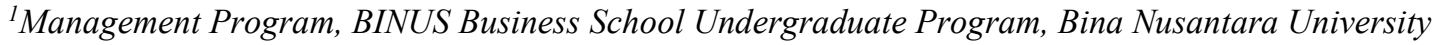 \\ ${ }^{2}$ International Relations Department, Bina Nusantara University \\ ${ }^{3}$ Doctor of Research in Management, Bina Nusantara University \\ ${ }^{4}$ Faculty of Economics and Business, University of Indonesia \\ lasmy@binus.edu*l
}

\begin{abstract}
Entrepreneurship has a significant role in a country's economy. Entrepreneurs such as Indonesia SMEs have a workforce absorption of up to 116.6 million people or $97.02 \%$ in 2017 , reaching 64 million units in 2018, able to contribute more than large-scale businesses to Indonesia's GDP amounted to $61.07 \%$ in 2018 and is predicted to increase to $65 \%$ in 2019 . However, Jokowi (2018) during his meeting with HIPMI said that the number of Indonesian entrepreneurs is still $3.1 \%$ while the standard in developed countries is more than $14 \%$. This statement indicates the urgency of the need to increase the number of Indonesian entrepreneurs. The increasing number of women and men entrepreneurs who are oriented towards business growth is very important for the economy because they are the ones who create jobs, absorb unemployment, reduce poverty, involve the community, have high productivity, innovation and export. In contradiction, Deputy Chairman of The Entrepreneur Markplus. Inc. \& President of the ICSB Indonesia and Chair of APINDO said that SMEs play a very important role in the Indonesian economy but not many SMEs competing for scaling up and even sustainability.
\end{abstract}

Keywords: Sensing Capability, Small Business, Performance

\section{INTRODUCTION}

Entrepreneurship has a significant role in a country's economy[1]. Entrepreneurs such as Indonesia SMEs have a workforce absorption of up to 116.6 million people or $97.02 \%$ in 2017 [2], reaching 64 million units in 2018 , able to contribute more than largescale businesses to Indonesia's GDP amounted to $61.07 \%$ in 2018 (Minister of Cooperatives and SMEs \& Indonesia, 2018) and is predicted to increase to $65 \%$ in 2019 [3]. However, Jokowi (2018) during his meeting with HIPMI (Indonesian Young Entrepreneurs Association) said that the number of Indonesian entrepreneurs is still $3.1 \%$ while the standard in developed countries is more than $14 \%$. This statement indicates the urgency of the need to increase the number of Indonesian entrepreneurs. The increasing number of women and men entrepreneurs who are oriented towards business growth is very important for the economy because they are the ones who create jobs, absorb unemployment, reduce poverty, involve the community, have high productivity, innovation and export [4].In contradiction, Deputy Chairman of The Entrepreneur Markplus. Inc. \& President of the ICSB (International Council for Small Business)
Indonesia, Dr. Jacky Mussry (2019) and Director of the Wismilak Group \& Chair of APINDO (Indonesian Entrepreneurs' Association), Ronald Walla (2019) said that SMEs play a very important role in the Indonesian economy but not many SMEs competing for scaling up and even sustainability. Small-scale businesses need to scale up so that economic growth also increases.

This is in line with one of the work programs of the Ministry of Cooperatives and SMEs which targets $6 \%$ of Indonesian small-scale businesses to scale up the class to middle class in the next 5 years [5]. The target of $6 \%$ is adjusted to the target of Indonesia's economic growth. Minister of Cooperatives and SMEs, TetenMasduki added that advancing class does not mean giving birth to new conglomerates but creating justice and ensuring national economic growth remains on a positive trend amid increasingly tough global challenges. Deputy for Business Restructuring, Abdul KadirDamanik, said that SMEs did not scaling up because they were not confident in technology, lack of knowledge, management skills, innovation, networking and capital [6].The number of mediumscale business units is still much smaller than the 
number of small-scale business units from 2010 to 2018 and the calculation of the annual growth rate (AGR) results in medium-scale businesses having an annual growth rate greater than $0.3 \%$ compared to small scale businesses. However, medium-scale businesses are able to make a greater contribution than small-scale businesses from 2010 to 2018 and the calculation of the AGR results in medium-scale businesses also contributing $0.7 \%$ more than smallscale businesses. The conclusion is that mediumscale businesses are able to make a better contribution to GDP with a much smaller number of units than small-scale businesses. So, if small-scale businesses can upgrade to medium-scale businesses, the proportion of GDP will be even better. One of the important abilities for an entrepreneur is sensing capability. Several studies have shown that sensing capability has a positive effect on business performance in Kenya [7], sensing capability plays an important role in business performance in the logistics industry [8] but different with [9] who argue that sensing capability has no significant effect on business performance in retail businesses.

\section{LITERATURE REVIEW}

Sensing capability is one of the five elements of dynamic capabilities that support organizational resilience [10] which includes sensing, searching, seizing, shifting, and shaping. Sensing capability is a company's activity in identifying, developing, and assessing opportunities related to customer needs; mobilization of resources in dealing with needs and opportunities, capturing value and transforming capabilities refers to changing or reconfiguring resources to maintain new or different values. It is important for an entrepreneur to have sensing capability, looking for opportunities especially to face today's dynamic conditions; sensing capability is an important element. Performance is an important thing that must be achieved by every company because performance is a reflection of the company's ability to manage and allocate its resources. The measurement of business performance is not enough to only measure financially such as sales growth, profit and ROI (Return of Investment), but also nonfinancial measurements such as customer satisfaction, employee satisfaction; reputation and innovation. The inconsistency of previous research results is related to sensing ability, namely some researchers argue that sensing capability is not positively related to retail business financial performance. Meanwhile, other researchers argue that sensing ability is part of dynamic capabilities and affects business performance. Other than that, findings reveal that there is no significant difference in sensing ability between women's and men's businesses at the beginning of the business year, but they differ significantly when the business has been running for a long time. Meanwhile, the findings state that there are significant differences in sensing abilities between men and women. The sensory ability of men is better than women. Research in relation to business performance conducted by argues that business performance those managed by women tend to be lower than those managed by men. Meanwhile, research by argues that the performance of businesses managed by men tends to be lower than those managed by women. On the other hand, research by argues that there is no link between the gender of entrepreneurs (both men and women) and business performance. Based on the review above, the following is a model of the framework in this study.

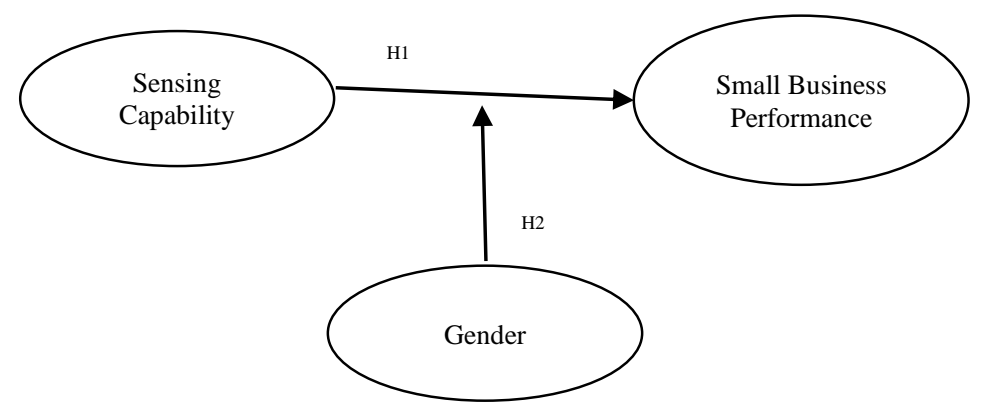

FIGURE 1. Research model

Hypothesis 1 : Sensing Capability has a positive effect on small business performance
Hypothesis 2 : Gender moderates the effect of sensing capability on small business performance 


\section{RESEARCH METHODS}

This research adopts a quantitative approach as a research method based on the philosophy of positivism, used to examine certain populations or samples, quantitative or statistical data analysis with the aim of testing predetermined hypotheses. The data collection time is cross sectional, that is, data will only be taken in a certain period to answer research questions. This study has 3 variables, namely 1 dependent variable, namely small business performance, 1 moderating variable, namely gender and 1 independent variable, namely sensing capability. Meanwhile, the industrial sector that will be examined in this research is the food and beverage industry sector. The food and beverage sector are researched because food and beverages are the basic needs of everyone and are one of the industrial sectors that still have the potential to grow even during the COVID-19 pandemic in 2020. Jakarta is the city with the highest per capita expenditure in Indonesia for 3 consecutive years, namely IDR
17,707 trillion in 2017, IDR 18,128 trillion in 2018 and IDR 18,527 trillion in 2019. These data indicate that the economic capacity of Jakarta is quite high. and the people have high consumptive abilities as well.

Therefore, Jakarta is the scope chosen in this study. Based on the BPS report, the number of small businesses in the DKI Jakarta province in 2018 was 9,791 units.Distribution of online questionnaires to small-scale food and beverage sector entrepreneurs in Jakarta, through available channels such as through associations, entrepreneur communities. The minimum sample required is 385 respondents. The sample calculation uses the Taro Yamane approach with a population of 9,791. Then analyse the data using SPSS.

\section{RESULT AND DISCUSSION}

The collected data amounted to 442 with the distribution of respondent profiles as follows

TABLE 1. Respondents Profile

\begin{tabular}{|l|c|c|}
\hline Gender Category & $\begin{array}{c}\text { Number of } \\
\text { respondents }\end{array}$ & Percentage \\
\hline Male & 221 & $50.0 \%$ \\
\hline Female & 221 & $50.0 \%$ \\
\hline Respondents age category & & \\
\hline $25-38$ years & 86 & $19.5 \%$ \\
\hline $39-58$ years & 161 & $36.4 \%$ \\
\hline$>59$ years & 7 & $1.6 \%$ \\
\hline$<24$ years & 188 & $42.5 \%$ \\
\hline Last Formal Education Category & & \\
\hline$<$ Senior High School & 226 & $51.1 \%$ \\
\hline Bachelor's degree(D1/D3/D4/S1/S2/S3) & 216 & $48.9 \%$ \\
\hline
\end{tabular}

shows that small-scale business actors are dominated by generation $\mathrm{Z}$, namely under 24 years of age by $42.5 \%$, while it is not significantly different from the last formal education between under or senior high school, namely $51.1 \%$ with those educated up to college, namely $48.9 \%$.

TABLE 2. Business Profile

\begin{tabular}{|l|c|c|}
\hline Business Age Category & $\begin{array}{c}\text { Number of } \\
\text { respondents }\end{array}$ & Percentage \\
\hline 3 - 5 years & 142 & $32.1 \%$ \\
\hline$>5$ years & 300 & $67.9 \%$ \\
\hline Category of Business Type & & \\
\hline Food & 214 & $48.4 \%$ \\
\hline Food \& Beverage & 179 & $40.5 \%$ \\
\hline Beverage & 49 & $11.1 \%$ \\
\hline Business Location Category & & \\
\hline West Jakarta & 118 & $26.7 \%$ \\
\hline Jakarta and Manado & 1 & $0.2 \%$ \\
\hline Central Jakarta & 52 & $11.8 \%$ \\
\hline South Jakarta & 79 & $17.9 \%$ \\
\hline East Jakarta & 88 & $19.9 \%$ \\
\hline North Jakarta & 104 & $23.5 \%$ \\
\hline
\end{tabular}




\begin{tabular}{|l|c|c|}
\hline Business Entity Category & & \\
\hline Do not have a business entity & 377 & $85.3 \%$ \\
\hline PT & 16 & $3.6 \%$ \\
\hline UD/CV/Firma & 49 & $11.1 \%$ \\
\hline Sales Scale Category & & \\
\hline International & 5 & $1.1 \%$ \\
\hline Local & 396 & $89.6 \%$ \\
\hline National & 32 & $7.2 \%$ \\
\hline National \& International & 9 & $2.0 \%$ \\
\hline Business Income Category in a Year & & \\
\hline 300 million - 500 million & 413 & $93.4 \%$ \\
\hline More than 1 billion - 2.5 billion & 14 & $3.2 \%$ \\
\hline More than 500 million - 1 billion & 15 & $3.4 \%$ \\
\hline
\end{tabular}

The results of validity and reliability tests show that all variables are valid and reliable.

TABLE 3. Validity \& Reliability Test Result

\begin{tabular}{|c|c|c|c|c|c|c|c|c|}
\hline Variabel & Indicator & rhitung & if & rtabel & result & $\begin{array}{l}\text { cronbach's } \\
\text { alpha }\end{array}$ & if & result \\
\hline \multirow{4}{*}{$\mathrm{SC}$} & SC.1 & 0.8 & $>$ & 0.098 & valid & \multirow{4}{*}{0.919} & \multirow{4}{*}{$>0.6$} & \multirow{4}{*}{ reliable } \\
\hline & SC. 2 & 0.841 & $>$ & 0.098 & valid & & & \\
\hline & SC.3 & 0.834 & $>$ & 0.098 & valid & & & \\
\hline & SC.4 & 0.781 & $>$ & 0.098 & valid & & & \\
\hline \multirow{7}{*}{ SBP } & SBP1.1 & 0.746 & $>$ & 0.098 & valid & \multirow{7}{*}{0.898} & \multirow{7}{*}{$>0.6$} & \multirow{7}{*}{ reliable } \\
\hline & SBP1.2 & 0.744 & $>$ & 0.098 & valid & & & \\
\hline & SBP1.3 & 0.641 & $>$ & 0.098 & valid & & & \\
\hline & SBP2.1 & 0.798 & $>$ & 0.098 & valid & & & \\
\hline & SBP2.2 & 0.632 & $>$ & 0.098 & valid & & & \\
\hline & SBP2.3 & 0.733 & $>$ & 0.098 & valid & & & \\
\hline & SBP2.4 & 0.648 & $>$ & 0.098 & valid & & & \\
\hline
\end{tabular}

The next test is the correlation test using SPSS. The results show that sensing capability has a positive and significant effect on small business performance. The higher the sensing capability, the higher the small business performance and vice versa. Meanwhile, the gender moderation variable did not have a significant effect on the sensing capability of the small business performance. These results may imply that the gender of the entrepreneur, both male and female, does not affect his sensing capability on business performance.

Model Summary

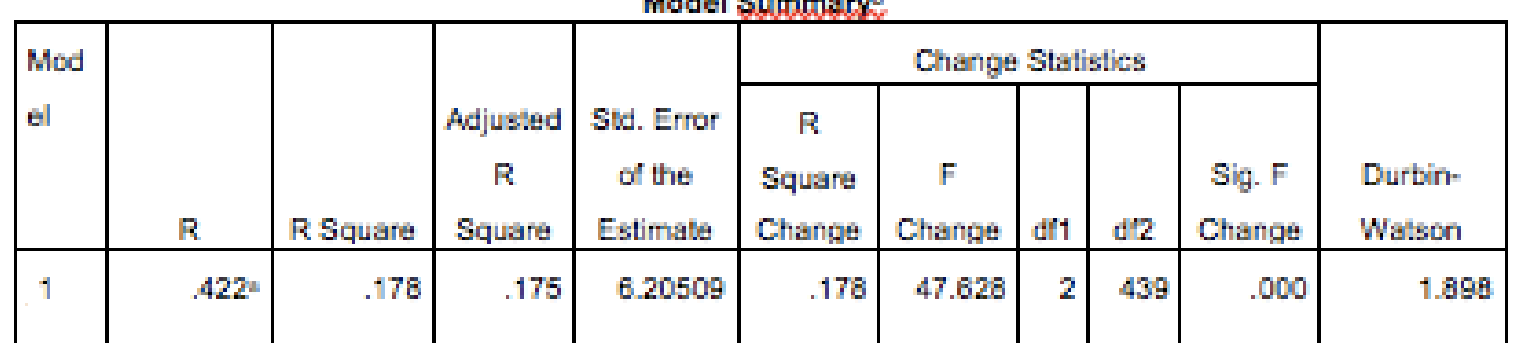

FIGURE 2. Model Summary 
Predictors: (Constant), Gender, X Dependent Variabel: Y

\begin{tabular}{|ll|r|r|r|c|c|}
\hline Model & & Sum of Squares & df & Mean Square & F & \multicolumn{1}{c|}{ Sia. } \\
\hline 1 & Regression & 3667.644 & 2 & 1833.822 & 47.628 & $.000^{\mathrm{a}}$ \\
& Residual & 16902.856 & 439 & 38.503 & & \\
Total & 20570.500 & 441 & & & \\
\hline
\end{tabular}

a. Predictors: (Constant), Gender, X

b. Dependent Variable: $Y$

FIGURE 3. ANOVA

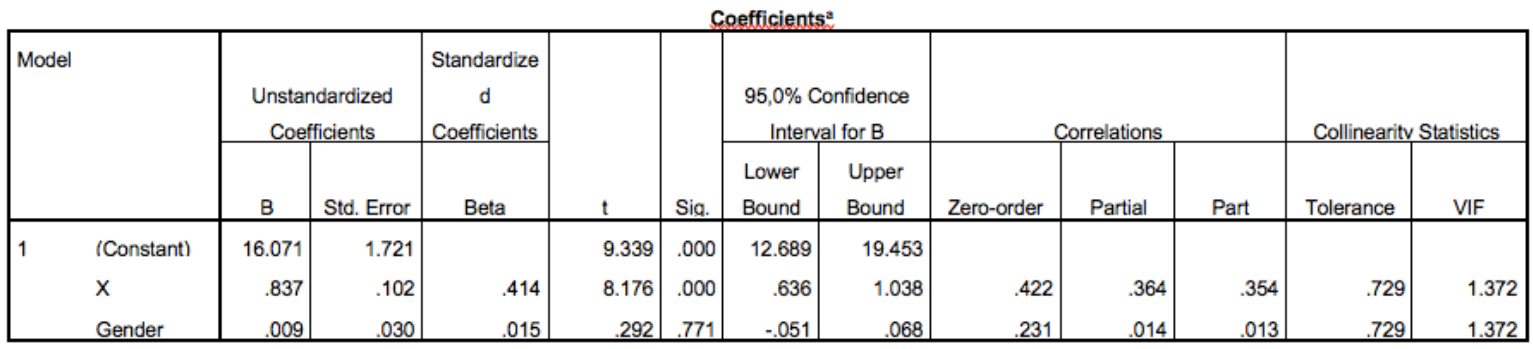

a. Dependent Variable: $Y$

FIGURE 4. Coefficients

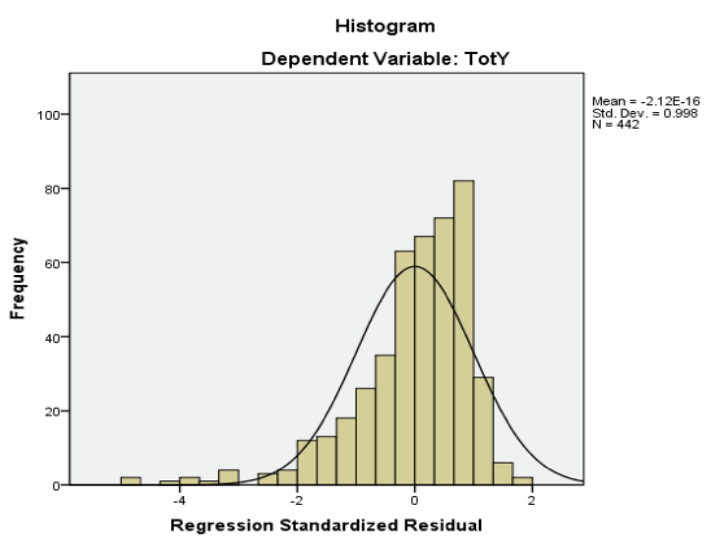

FIGURE 5. Histogram

\section{CONCLUSION}

Based on the results of data testing, the conclusion is that it is important for an entrepreneur to have a strong sensing capability such as identifying opportunities, market needs, trends, being able to understand customer spending behaviour so that they are able to take strategic policies in an effort to improve business performance. Increasing sensing capability can be done by participating in entrepreneurship training, joining a community or entrepreneur association. Then this study also concluded that gender does not affect the sensing capability of an entrepreneur on his business performance. This research still has various limitations. Therefore, researchers suggest that further research can be carried out such as adding training variables, ecosystems and expanding the scope of research outside Jakarta.

\section{REFERENCES}

[1] E. Pereverzeva, Key Elements of the Entrepreneurial Ecosystem Facilitating the Growth of ICT Entrepreneurs in Russia. Entrepreneurship in BRICS, 65-90. 
https://doi.org/10.1007/978-3-319-11412-5. 2015.

[2] Coordinating Ministry for Economics Affair of The Republic of Indonesia., Weekly economics report. Retrieved from https://ekon.go.id/ekliping/view/edisi-13-42019-laporan.4755.html. 2019.

[3] D. Syarizka, Kontribusi UMKM terhadap PDB 2019 Diproyeksi Tumbuh 5\%. Retrieved March 4, 2020, from https://ekonomi.bisnis.com/read/20190109/ 12/876943/kontribusi-umkm-terhadap-pdb2019-diproyeksi-tumbuh-5. 2019.

[4] R. Mason, C., \& Brown, Creating good public policy to support high-growth firms. Small Business Economics, 40(2), 211-225. https://doi.org/10.1007/s11187-011-93699. 2013.

[5] Depkop.go.id, UMKM NAIK KELAS KEJAR PERTUMBUHAN WIRAUSAHA. Diakses pada 15 Juni 2020, dari http://www.depkop.go.id/read/umkm-naikkelas-kejar-pertumbuhan-wirausaha. 2020.

[6] Pasardana.id, Kemenkop UKM Usahakan UMKM Untuk Naik Kelas. Diakses pada 15 Juni 2020, dari https://pasardana.id/news/2019/11/27/keme nkop-ukm-usahakan-umkm-untuk-naikkelas/. .

[7] K. Kihara, A. S. N., Ngugi, P. K., \& Ogollah, INFLUENCE OF DYNAMIC CAPABILITIES ON PERFORMANCE OF LARGE MANUFACTURING FIRMS IN KENYA. L, 2(1), 106-126. 2016.

[8] D. H. Sudrajat, D., Saroso, H., Lasmy, Herlina, M. G., \& Syahchari, The role of sensing capability in improving financial performance of logistics service firms. International Journal of Innovation, Creativity and Change, 10(9), 153-167. 2019.

[9] S. Lindblom, A. T., Olkkonen, R. M., Mitronen, L., \& Kajalo, Market-Sensing Capability and Business Performance of Retail Entrepreneurs. Contemporary Management Research, 4(3), 219-236. https://doi.org/10.7903/cmr.1042. 2008.

[10] A. Baškarada, S., \& Koronios, The $5 S$ organizational agility framework: a dynamic capabilities perspective. International Journal of Organizational Analysis, 26(2), 331-342. https://doi.org/10.1108/IJOA-05-20171163 . . 